\title{
Dysregulation of In Vitro Cytokine Production by Monocytes during Sepsis
}

\author{
Carlos Munoz, ${ }^{\star}$ Jean Carlet, ${ }^{\ddagger}$ Catherine Fitting, ${ }^{*}$ Benoit Misset, ${ }^{\star}$ Jean-Pierre Blériot, ${ }^{\star}$ and Jean-Marc Cavaillon* \\ *Unité d'Immuno-Allergie, Institut Pasteur, Paris, and ${ }^{\ddagger}$ Intensive Care Unit, Hôpital Saint Joseph, Paris, France
}

\begin{abstract}
The production by monocytes of interleukin-1 $\alpha(\mathrm{IL}-1 \alpha)$, interleukin-1 $\beta$ (IL-1 $\beta)$, interleukin-6 (IL-6), and tumor necrosis factor alpha (TNF $\alpha)$ in intensive care unit (ICU) patients with sepsis syndrome $(n=23)$ or noninfectious shock $(n=6)$ is reported. Plasma cytokines, cell-associated cytokines within freshly isolated monocytes and LPS-induced in vitro cytokine production were assessed at admission and at regular intervals during ICU stay. TNF $\alpha$ and IL- 6 were the most frequently detected circulating cytokines. Despite the fact that $\mathrm{IL-1} \alpha$ is the main cytokine found within monocytes upon in vitro activation of cells from healthy individuals, it was very rarely detected within freshly isolated monocytes from septic patients, and levels of cell-associated IL-1 $\beta$ were lower than those of TNF $\alpha$. Cell-associated IL-1 $\beta$ and TNF $\alpha$ were not correlated with corresponding levels in plasma. Upon LPS stimulation, we observed a profound decrease of in vitro IL-1 $\alpha$ production by monocytes in all patients, and of $\mathrm{IL}-1 \beta, \mathrm{IL}-6$, and TNF $\alpha$ in septic patients. This reduced LPS-induced production of cytokines was most pronounced in patients with gram-negative infections. Finally, monocytes from survival patients, but not from nonsurvival ones recovered their capacity to produce normal amounts of cytokines upon LPS stimulation. In conclusion, our data indicate an in vivo activation of circulating monocytes during sepsis as well as in noninfectious shock and suggest that complex regulatory mechanisms can downregulate the production of cytokines by monocytes during severe infections. ( $J$. Clin. Invest. 1991. 88:1747-1754.) Key words: interleukin-1 • interleukin-6 6 tumor necrosis factor • endotoxin • infection
\end{abstract}

\section{Introduction}

Cytokines are essential for hematopoiesis and immune responses, and play a key role in the defense against infectious diseases. In animal models, circulating IL-1, IL-6, and tumor necrosis factor (TNF) ${ }^{1}$ have been documented after injection of whole bacteria or endotoxins prepared from gram-negative bacteria or toxins derived from gram-positive bacteria (1-7). Similarly in human, bolus injection of LPS induces a transient

Carlos Munoz's present address is Immunology Unit, INTA, Universidad de Chile, Casilla 15138, Santiago 11, Chile.

Address correspondence to Jean-Marc Cavaillon, Unité d'Immuno-Allergie, Institut Pasteur, 28 rue Dr. Roux, 75724 Paris Cedex 15, France.

Received for publication 15 January 1991 and in revised form 29 May 1991

1. Abbreviations used in this paper: ARDS, adult respiratory distress syndrome; SAPS, simplified acute physiological score; TNF, tumor necrosis factor.

J. Clin. Invest.

(C) The American Society for Clinical Investigation, Inc.

$0021-9738 / 91 / 11 / 1747 / 08 \$ 2.00$

Volume 88, November 1991, 1747-1754 appearance of IL-1, TNF $\alpha$, and IL-6 in plasma (8-10). The presence of circulating cytokines has been often reported in the plasma of infected patients (10-19). Most of the deleterious effects of microbial toxins, especially endotoxins, can be mimicked by IL-1 and TNF. This was demonstrated in case of pulmonary injury $(20,21)$, adult respiratory distress syndrome (ARDS) $(22,23)$, hemodynamic, and cardiovascular dysfunctions (24-26), intravascular coagulation $(27,28)$, and tissue lesions $(29,30)$. IL-6, together with IL-1 and TNF, plays a major role in the production of acute phase proteins by hepatocytes (31-33) and in fever $(34,35)$. In addition, these cytokines are able to induce each other via cascade events (36-40), and potentiation of pathologic effects are observed consecutively to the synergistic action of these mediators together (41-44), or with bacterial products (45). Levels of TNF have been associated with the severity of illness (18) and amounts of circulating TNF and IL-6 have been reported to correlate with the prognosis of the disease (10-13, 17-19). During infection, the major cytokine production is very probably consecutive to a nonspecific activation of monocytes/macrophages by microbial-derived products. The exact nature of the cells involved in the process leading to the presence of circulating cytokines has been poorly studied. We had previously shown in hemodialyzed patients that the presence of IL-1 activity in cell lysates could reflect the in vivo monocyte activation (46). Such an in vivo activation has also been reported by Haeffner-Cavaillon et al. (47) who observed the presence of IL-1 $\beta$ in cell lysates from monocytes of patients undergoing cardiopulmonary bypass. Thus, in order to characterize the origin of the circulating cytokines, we measured IL-1, TNF $\alpha$, and IL- 6 production by monocytes from patients with sepsis. Because cytokines, mainly IL1 , can be accumulated within the cells, we investigated the content of freshly isolated monocytes and we studied the capacity of these cells to release in vitro these cytokines in the absence of exogeneous stimulus as well as after endotoxin stimulation.

\section{Methods}

Patients. 29 patients admitted to the Intensive Care Unit (ICU) were studied (Table I). 23 (15 males, 8 females; mean age \pm SD $=65 \pm 15$; range, 32-81) fulfilled the criteria for the sepsis syndrome as described by Bone et al. (48), including evidence of an infectious site and a sign of inadequate organ perfusion (mental dysfunction, hypoxemia, elevated plasma lactate, or oliguria). Of these, 14 met the criteria for septic shock (sepsis syndrome plus a systolic BP $<90 \mathrm{mmHg}$ or a decrease from baseline in systolic BP $>40 \mathrm{mmHg}$ ), and seven met the criteria for ARDS (bilateral alveolar infiltrates, pulmonary wedged pressure $<18$ $\mathrm{mmHg}$, and $\mathrm{PaO}_{2} / \mathrm{FiO}_{2}<150$ with positive expiratory pressure $\geq 5 \mathrm{~cm}$ $\mathrm{H}_{2} \mathrm{O}$ ). The infectious conditions included pneumonia $(n=8)$, peritonitis $(n=4)$, catheter-related sepsis $(n=3)$, pyelonephritis $(n=2)$, infectious aortic aneurism $(n=1)$, aortic graft sepsis $(n=1)$, cholangitis $(n=1)$, cellulitis $(n=1)$, meningitis $(n=1)$, and meningococcal arthritis $(n=1)$. The pathogenic agents were gram-negative bacilli (GNB) in nine cases, gram-positive cocci (GPC) in seven, association of GNB and GPC in six, and Mycobacterium tuberculosis in one. 10 patients were bacteremic. The simplified acute physiologic score (49) on admis- 
Table I. Clinical Parameters of the ICU Patients

\begin{tabular}{|c|c|c|c|c|c|c|c|}
\hline Infections & Patients & $\begin{array}{l}\text { Infection site } \\
\text { or type of shock }\end{array}$ & Outcome* & Shock & ARDS $^{\ddagger}$ & $\begin{array}{l}\text { Initial } \\
\text { SAPS }\end{array}$ & Bacteremia \\
\hline \multirow[t]{9}{*}{ Gram-negative bacteria } & 1 & Pneumonia & $\mathbf{R}$ & yes & no & 12 & yes \\
\hline & 2 & Infect. aortic aneurism & D & yes & no & 10 & yes \\
\hline & 3 & Pneumonia & $\mathbf{R}$ & yes & no & 9 & no \\
\hline & 4 & Pyelonephritis & $\mathbf{R}$ & yes & no & 13 & yes \\
\hline & 5 & Pneumonia & $\mathbf{R}$ & yes & no & 18 & no \\
\hline & 6 & Cholangitis & D & yes & yes & 23 & yes \\
\hline & 7 & Peritonitis & D & yes & no & 15 & no \\
\hline & 8 & Pneumonia & D & yes & yes & 18 & no \\
\hline & 9 & Septicemia arthritis & $\mathbf{R}$ & yes & no & 11 & yes \\
\hline \multirow{6}{*}{$\begin{array}{l}\text { Combination of gram-negative } \\
\text { and gram-positive bacteria }\end{array}$} & 10 & Meningitis & $\mathbf{R}$ & yes & no & 19 & yes \\
\hline & 11 & Peritonitis & D & yes & yes & 15 & no \\
\hline & 12 & Peritonitis & $\mathbf{R}$ & no & no & 16 & no \\
\hline & 13 & Pneumonia & $\mathbf{R}$ & yes & yes & 9 & no \\
\hline & 14 & Intravasc. catheter & $\mathbf{R}$ & yes & no & 12 & no \\
\hline & 15 & Pyelonephritis & $\mathbf{R}$ & no & no & 13 & no \\
\hline \multirow[t]{7}{*}{ Gram-positive bacteria } & 16 & Aortic graft & D & no & yes & 14 & no \\
\hline & 17 & Intravasc. catheter & $\mathbf{R}$ & no & yes & 14 & yes \\
\hline & 18 & Endocarditis & $\mathbf{R}$ & no & no & 5 & yes \\
\hline & 19 & Intravasc. catheter & $\mathbf{R}$ & no & yes & 9 & yes \\
\hline & 20 & Pneumonia & $\mathbf{R}$ & no & no & 8 & yes \\
\hline & 21 & Pneumonia & $\mathbf{R}$ & no & no & 8 & no \\
\hline & 22 & Cellulitis & $\mathbf{R}$ & yes & no & 13 & no \\
\hline Tuberculosis & 23 & Tubercul. pneumonia & D & no & no & 13 & no \\
\hline Mean & & & $30 \% \mathrm{D}$ & $61 \%$ shock & $30 \%$ ARDS & $12.9 \pm 4.2$ & $43 \%$ bacteremia \\
\hline \multirow[t]{6}{*}{ No infection } & 24 & Cardiogenic & D & yes & yes & 15 & no \\
\hline & 25 & Hypovolaemic & $\mathbf{R}$ & yes & no & 7 & no \\
\hline & 26 & Cardiogenic & D & yes & no & 14 & no \\
\hline & 27 & Cardiogenic & D & yes & yes & 12 & no \\
\hline & 28 & Hemorrhagic & $\mathbf{R}$ & yes & no & 9 & no \\
\hline & 29 & Hemorrhagic & $\mathbf{R}$ & yes & no & 19 & no \\
\hline Mean & & & $50 \% \mathrm{D}$ & $100 \%$ shock & $33 \%$ ARDS & $12.7 \pm 4.3$ & none \\
\hline
\end{tabular}

${ }^{*} \mathrm{R}=$ recovery; $\mathrm{D}=$ death. ${ }^{\ddagger}$ Adult respiratory distress syndrome. ${ }^{8}$ Simplified acute physiological score.

sion was $12.9 \pm 4.2$ (mean \pm SD) for the 23 septic patients. All infected patients (mean weight $\pm \mathrm{SD}=66 \pm 14 \mathrm{~kg}$; range, 33-90) received parenteral feeding (glucids + lipids $=1,650 \pm 605 \mathrm{kCal} / \mathrm{d}$, nitrogen $9.5 \pm 5.5$ $\mathrm{g} / \mathrm{d})$. Treatment of infected patients included antibiotics $(n=23)$, morphinics and benzodiazepin $(n=15)$, heparin $(n=19)$, catecholamines $(n=12)$, corticosteroides $(n=3 ; 0.5-1 \mathrm{mg} / \mathrm{kg}$ per d), insulin $(n=7)$, and cyclooxygenase inhibitors $(n=2)$.

The six remaining patients (five males, one female; mean age $=64 \pm 18$; range, $31-78)$ were admitted because of cardiogenic $(n=3)$, hemorrhagic $(n=2)$, or hypovolemic shocks $(n=1)$. The simplified acute physiologic score on admission was $12.7 \pm 4.3$. All patients with noninfectious shock (mean weight $=71 \pm 17 \mathrm{~kg}$; range, 56-100) received parenteral feeding (glucids + lipids $=1,465 \pm 525 \mathrm{KCal} / \mathrm{d}$; nitrogen $=13 \mathrm{~g} / \mathrm{d})$. Their treatment included antibiotics $(n=3)$, morphinics $(n=5)$, benzodiazepin $(n=4)$, cyclooxygenase inhibitors $(n=1)$, catecholamines $(n=3)$, heparin $(n=4)$, and insuline $(n=2)$.

10 patients died in the ICU. Healthy controls $(n=14)$ were donors of either sex from the blood bank and research workers from our laboratory.

Collection of blood samples. Blood was collected within $2 \mathrm{~d}$ after admission of the patients in the ICU, daily during the 3 following days, and then weekly until day 14 or 21 if the patients were still in the ICU. Last measurements were performed on day $14 \pm 1.5$ (range, 5-21) for survival patients and on day $7 \pm 2.5$ (range, 1-21) for nonsurvival patients.

Plasma. $20 \mathrm{ml}$ of blood were drawn on EDTA. Blood was immediately placed in ice and processed within 2 h. $200 \mu \mathrm{l}$ of aprotinin (a protease inhibitor; $0.67 \mathrm{TUI} / \mathrm{ml}$ of blood) (Sigma Chemical Co., St. Louis, MO) were added and tubes were centrifuged at $400 \mathrm{~g}$ and $4^{\circ} \mathrm{C}$ for $10 \mathrm{~min}$. Plasma was transferred in eppendorf tubes and further centrifuged at $10,000 \mathrm{~g}$ and $4^{\circ} \mathrm{C}$ for $5 \mathrm{~min}$. Plasma was then aliquoted and kept at $-30^{\circ} \mathrm{C}$.

Monocytes. Cell pellet was resuspended to $25 \mathrm{ml}$ in RPMI-1640 medium (Gibco, Grand Island, NY) and centrifuged over ficoll (Milieu de Separation des Lymphocytes, Eurobio, Les Ul, France) for $25 \mathrm{~min}$ at $150 \mathrm{~g}$ at room temperature. After washing peripheral blood mononuclear cells were numerated and nonspecific esterase (NSE) staining performed (50). $5 \times 10^{5} \mathrm{NSE}^{+}$cells/0.5 ml RPMI medium/well (24-well multidish plates, Falcon Labware, Oxnard, CA) were let to adhere for 1 $\mathrm{h}$ as previously described $(51)$.

Collection of cell-associated cytokine content. Immediately after adherence, nonadherent cells were removed, adherent cells were washed, 
and $0.5 \mathrm{ml}$ of fresh RPMI medium were added. The plates were then frozen as previously described (52). Three cycles of freezing-thawing were performed before harvesting the cell lysate which was then centrifuged and kept at $-30^{\circ} \mathrm{C}$ before cytokine content assessments.

In vitro cultures. In vitro cultures were performed as previously described $(50,51)$. Briefly, after washing, adherent cells were cultured for $24 \mathrm{~h}$ in $0.5 \mathrm{ml}$ RPMI-1640 medium supplemented with antibiotics, $1 \mu \mathrm{g} / \mathrm{ml}$ indomethacin, and $0.2 \%$ normal human serum, in the absence (spontaneous cytokine production) or in the presence of $2 \mu \mathrm{g} / \mathrm{ml} \mathrm{Neis-}$ seria meningitidis LPS kindly provided by Dr. M. Caroff (Institut Biochimie, Orsay, France). This LPS was specially chosen for its potency to induce cytokine production (53). At the end of the culture, supernatants were harvested, and cell lysates prepared as described above.

IL-6 bioassay. IL- 6 activity was determined by using the specific 7TD1 IL-6-dependent cell line (54) kindly provided by Dr. J. Van Snick (Ludwig Institute for Cancer Research, Brussels). Cells were cultured at a density of 1,200 cells/well (96-well multidish plates, Falcon Labware, Oxnard, CA) in $100 \mu$ l of RPMI medium supplemented with antibiotics, 2-mercaptoethanol $\left(5 \times 10^{-5} \mathrm{M}\right)$ and $10 \% \mathrm{FCS}$, in the presence of serial dilutions of cell supernatants or heat inactivated $(30 \mathrm{~min}$, $56^{\circ} \mathrm{C}$ ) plasma. After $4 \mathrm{~d}$ of culture at $37^{\circ} \mathrm{C}$, the proliferation was monitored by a dye method (55). Briefly, $125 \mu \mathrm{g}$ of tetrazolium salts (MTT) were added to each well and after $1-2 \mathrm{~h}$ of incubation at $37^{\circ} \mathrm{C}$, the test was then stopped with $100 \mu \mathrm{l} /$ well of an extraction buffer (20\% SDS, $50 \%$ DMF in $\mathrm{H}_{2} \mathrm{O}, 2.5 \% \mathrm{HCl} 1 \mathrm{~N}, 2.5 \%$ of an $80 \%$ acetic acid solution, pH 7.4). After an overnight incubation at $37^{\circ} \mathrm{C}$, the optical densities were measured at $540 \mathrm{~nm}$ using an automated microELISA autoreader. 1 U of IL- 6 corresponds to half-maximum growth of the hybridoma cells. IL-6 activity detected in supernatants of LPS-stimulated monocytes and in plasma was completely abolished by the addition of $10 \mu \mathrm{g}$ rabbit polyclonal anti-human IL-6 antibodies (Genzyme Corp., Boston, MA).

$T N F \alpha R I A$. The TNF $\alpha$ RIA was based on a competitive inhibition assay for TNF $\alpha$ as developed by Van der Meer et al. (56), and modified in our laboratory. In every assay, 10 standards of TNF $\alpha$ (Rhône Poulenc, France) containing $0,40,80,150,300,600,1,250,2,500,5,000$, and $10,000 \mathrm{pg} / \mathrm{ml}$ were employed. All standards and cell supernatant or cell lysate samples were diluted in a BSA buffer. TNF $\alpha$ in plasma was assessed in undiluted samples. On day $1,100 \mu \mathrm{l}$ of a rabbit anti-TNF $\alpha$ antiserum (a kind gift of Catherine Rougeot, Institut Pasteur) diluted 1:10,000 to precipitate $35 \%$ of the radiolabeled TNF was added to 100 $\mu \mathrm{l}$ of standards or samples. To determine the nonspecific binding, 100 $\mu \mathrm{l}$ of BSA buffer was added to a tube instead of sample. Then $300 \mu \mathrm{l}$ of BSA buffer were added to each tube. After vortexing, the tubes were incubated for $24 \mathrm{~h}$ at room temperature. On day $2,100 \mu \mathrm{l}$ of ${ }^{125} \mathrm{I}-\mathrm{TNF} \alpha$ solution $(30 \mu \mathrm{Ci} / \mu \mathrm{g}$, New England Nuclear, Boston, MA) containing $\sim 10,000 \mathrm{cpm}$ was added to each tube, and after vortexing left for a further incubation at room temperature for $24 \mathrm{~h}$. On day $3,500 \mu \mathrm{l}$ of BSA buffer containing $6 \%$ of polyethylene glycol 8000 (Sigma Chemical Co.), $1 \%$ of horse anti-rabbit IgG (C. Rougeot, Institut Pasteur) and $0.1 \%$ of normal rabbit serum were added. The tubes were vortexed and incubated for $1 \mathrm{~h}$ at room temperature. The tubes were then centrifuged at $1,500 \mathrm{~g}$ for $15 \mathrm{~min}$ at room temperature. Thereafter, the supernatants were discarded and the tubes were kept inverted for $30 \mathrm{~min}$ and drained on absorbant paper. Tubes were counted in a gamma counter and the value for nonspecific binding was subtracted. All standards and samples were expressed as percentage of the standard containing no $\mathrm{TNF} \alpha$ (zero standard). The concentrations of TNF $\alpha$ in $\mathrm{pg} / \mathrm{ml}$ on the logarithmic $x$-axis were plotted against the binding percentage on a logarithmic $y$-axis. The standard curve obtained was used to determine the concentrations of TNF $\alpha$ in samples. The detection limit was 70 $\mathrm{pg} / \mathrm{ml}$ (set binding of $95 \%$ of zero standard).

$I L-1 \beta R I A$. To remove putative factors present in plasma that interfere with IL-1 $\beta$ RIA, a chloroform extraction was performed as described by Cannon et al. (57). $1 \mathrm{ml}$ of chloroform was transfered in 1.5 $\mathrm{ml}$ eppendorf tube containing $500 \mu \mathrm{l}$ of plasma. Each tube was mixed vigorously for $10 \mathrm{~min}$ and centrifuged at $10,000 \mathrm{~g}$ for $10 \mathrm{~min}$ at $4^{\circ} \mathrm{C}$. This operation was repeated twice. The tube was left undisturbed for 20 $\mathrm{min}$ at room temperature. The aqueous phase was collected and stored at $-30^{\circ} \mathrm{C}$ until assaying. A similar RIA protocol as that used for TNF $\alpha$ measurement was employed to determine the concentration of IL-1 $\beta$. Standard IL-1 $\beta$ was obtained from Rhône Poulenc (France), rabbit anti-IL-1 $\beta$ antiserum diluted (1:100) was purchased from Genzyme Corp. and ${ }^{125}$ I-IL-1 $\beta(126-253 \mu \mathrm{Ci} / \mu \mathrm{g})$ from New England Nuclear. On day $3,500 \mu$ l of BSA buffer containing $6 \%$ polyethylene glycol $8000,1 \%$ of sheep anti-rabbit IgG (Sigma Chemical Co.) and 0.05\% normal rabbit serum were added to each tube. Determination of IL- $1 \beta$ concentrations in plasma and samples were calculated as described above. The detection limit was $70 \mathrm{pg} / \mathrm{ml}$.

$I L-1 \alpha E L I S A$. The IL-1 $\alpha$ concentrations were determined by a specific ELISA method developed in our laboratory using two anti-IL- $1 \alpha$ monoclonal antibodies which have been obtained in collaboration with J.-C. Mazié (Hybridolab, Institut Pasteur). After immunization of $\mathrm{Balb} / \mathrm{c}$ mice with recombinant human interleukin-1 $\alpha$ (hrIL-1 $\alpha$ ) kindly provided by Rhône Poulenc, spleen cells were fused with X63-Ag8.653 mouse myeloma cells (58). Hybridoma cells were then tested for antibody production against IL- $1 \alpha$ by ELISA. Cells from positive wells were cloned by limiting dilutions in microtiter plates. Immunoglobulin subclass determinations were performed using MAb isotyping from Amersham International, Amersham, UK). Hybridomas were expanded for antibody production by intraperitoneal injection into pristane-primed mice. Two antibodies were selected: one monoclonal (289) is an IgG1, and the other (2-12) is an IgG2b. They do not recognize the same epitope on IL- $1 \alpha$ molecule as judged by competition ELISA and do not bind to IL- $1 \beta$. Both inhibit the biological activity of IL- $1 \alpha$ in the thymocyte comitogenic assay.

On day 1 , Luxlon ELISA microtiter plates were coated with $100 \mu \mathrm{l}$ of monoclonal mouse IgG1 anti-rhIL-1 $\alpha(10 \mu \mathrm{g} / \mathrm{ml}$ in carbonate buffer) and incubated $2 \mathrm{~h}$ at $37^{\circ} \mathrm{C}$. The plates were washed three times with $0.1 \%$ tween-20 PBS. Standards $(0,10,30,100,300,1,000,3,000$, and $10,000 \mathrm{pg} / \mathrm{ml}$ rhIL-1 $\alpha$ ) or cell supernatant or cell lysate samples diluted in $1 \%$ BSA, 0.1\% Tween-20 PBS were added to coated wells and incubated overnight at $4^{\circ} \mathrm{C}$. On day 2 , the plates were washed three times and $100 \mu \mathrm{l}$ of the second monoclonal mouse anti-rhIL-1 $\alpha$ (IgG2b) $(1: 2,000$ in BSA/Tween/PBS) were added into each well. Plates were incubated for $3 \mathrm{~h}$ at $37^{\circ} \mathrm{C}$. After washing, $100 \mu \mathrm{l}$ of peroxydase conjugate anti-mouse IgG2b $(1: 1,000)$ (ICN Biomedicals, Inc., Irvine, $\mathrm{CA}$ ) were added to each well and the plates were left for $1 \mathrm{~h}$ at $37^{\circ} \mathrm{C}$. After washing, enzymatic activity was detected with a phosphate citrate buffer containing $1 \mathrm{mg} / \mathrm{ml} O$-phenylenediamine dihydroxychloride (Sigma Chemical Co.) and hydrogen peroxyde $(0.06 \%)$. The reaction was stopped with $50 \mu \mathrm{l}$ of $\mathrm{HCl} 3 \mathrm{~N}$ and the absorbance was read at $492 \mathrm{~nm}$ in a microplate reader (Titertek multiskan MC340; Flow Laboratories, Inc., McLean, VA). The levels of IL-1 $\alpha$ in the samples were calculated by reference to the standard curve. The detection limit of IL- $1 \alpha$ was $30 \mathrm{pg} / \mathrm{ml}$.

All cytokine measurements have been assessed using the international standards (National Institute for Biological Standards and Controls, Herfordshire, UK).

Statistical analysis. Statistical analyses were carried out using the paired or unpaired student $t$ test.

\section{Results}

Circulating cytokines. Cytokines were under detection limits in plasma of healthy controls. The levels of plasma TNF $\alpha$, IL-6, and IL- $1 \beta$ at admission and the maximum levels of circulating cytokines during longitudinal survey are plotted in Table II. No IL- $1 \alpha$ could be detected. Circulating TNF $\alpha$ could be detected in $86 \%$ of the patients, IL-6 in $83 \%$, and IL- $1 \beta$ in only $57 \%$ of the patients. Maximum levels of TNF $\alpha$ and IL- $1 \beta$ were significantly higher than the corresponding levels at admission. Significant amounts of circulating cytokines were also observed in patients with nonseptic shock. At the end of the survey, only two among 16 survival infected patients still had detectable 
Table II. Mean of Plasma Cytokines Levels Measured within 2 d after Patients Admission in the ICU Compared to the Maximum Values Observed during the Longitudinal Study of Septic Patients and Patients with Nonseptic Shock

\begin{tabular}{|c|c|c|c|c|c|c|}
\hline & TNF $\alpha$ & $P^{*}$ & $\mathrm{IL}-1 \beta$ & $P$ & IL-6 & $P$ \\
\hline & $p g / m l$ & & $p g / m l$ & & $U / m l$ & \\
\hline First determination & $133 \pm 23$ & & $188 \pm 51$ & & $1079 \pm 396$ & \\
\hline Range (\% patients) & $0-420(66 \%)$ & & $0-1630(54 \%)$ & & $0-11800(77 \%)$ & \\
\hline Maximum observation & $197 \pm 20$ & $<0.001$ & $305 \pm 74$ & 0.01 & $4172 \pm 2011$ & 0.08 \\
\hline Range (\% patients) & $0-470(86 \%)$ & & $0-1630(57 \%)$ & & $0-46000(83 \%)$ & \\
\hline
\end{tabular}

* Comparisons between first determination at admission in ICU and the maximum observation, paired Student $t$ test.

plasma TNF $\alpha$, whereas six of seven nonsurvival patients had circulating TNF $\alpha$.

Cell-associated cytokines in freshly isolated monocytes. Cell-associated IL- $1 \alpha$ and IL- $1 \beta$ were never detected in lysates of freshly isolated monocytes from healthy donors, and most controls had no TNF $\alpha(50 \pm 29 \mathrm{pg} / \mathrm{ml})$. Maximum levels of cellassociated IL- $1 \alpha$, IL- $1 \beta$, and TNF $\alpha$ in monocytes of patients with sepsis syndrome are shown in Fig. 1. Data at admission were not significantly different from the maximum levels observed during the longitudinal survey. IL- $1 \alpha$ was usually absent in cell lysates and only found in $35 \%$ of septic patients. IL-6 was not found in monocytes lysates. $56 \%$ of the septic patients had cell-associated IL- $1 \beta$ at any time of the evolution (mean \pm SEM $=206 \pm 73 \mathrm{pg} / \mathrm{ml}$ ), and $91 \%$ of the patients had cell associated TNF $\alpha(625 \pm 126 \mathrm{pg} / \mathrm{ml})$. Patients with nonseptic shock had also significant amounts of cell-associated cytokines (data not shown). No differences were noticed between the levels of cellassociated IL- $1 \beta$ and TNF $\alpha$ in monocytes of survival or nonsurvival patients. No correlation was found between plasmatic and cell-associated levels of IL- $1 \beta$ and TNF $\alpha$. Furthermore, although at the end of the longitudinal study, plasma levels of TNF $\alpha$ were under detection limits in 14 of 16 survival infected patients, significant levels of cell-associated TNF $\alpha$ were still detectable in 14 of 16 patients.

In vitro cytokine production upon LPS stimulation. At admission, a decreased in vitro cytokine production by mono-

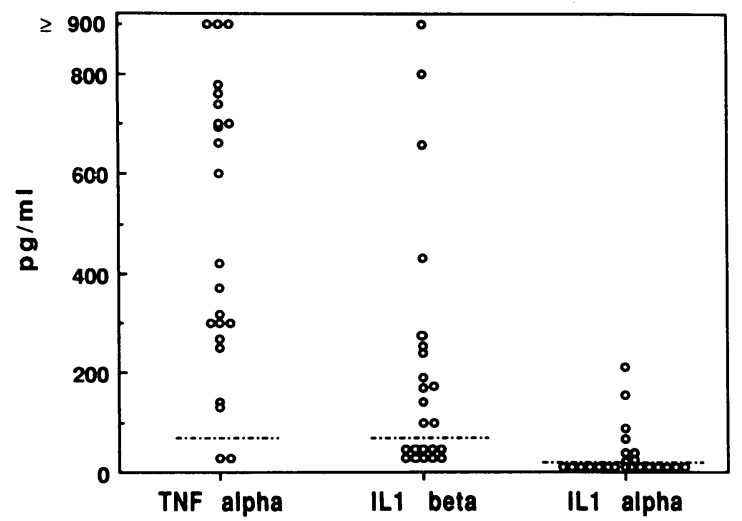

Figure 1. Maximum amounts of cell-associated cytokines found within freshly isolated monocytes from septic patients. (Mean \pm SEM of TNF $\alpha=625 \pm 126 \mathrm{pg} / \mathrm{ml}$; mean \pm SEM of IL $-1 \beta=206 \pm 73 \mathrm{pg} / \mathrm{ml}$; $P=0.005$ ). Dotted lines represent the detection limits for TNF $\alpha$, IL$1 \beta$, and IL- $1 \alpha$, respectively. cytes upon stimulation by LPS was noticed among infected patients as compared to healthy controls (Fig. 2). The initial levels were not significantly different between survival and nonsurvival patients. During the longitudinal survey, minimum levels of released IL- $1 \alpha$, IL- $1 \beta$, TNF $\alpha$, and IL- 6 and cellassociated IL- $1 \alpha$ and IL- $1 \beta$ were reached. Comparisons to the levels of cytokine productions by monocytes from the healthy control group, are shown in Table III. Significant decreased levels of released and cell-associated IL- $1 \alpha$ and IL- $1 \beta$ and released IL- 6 and TNF $\alpha$ were noted in all ICU infected patients. The patients with gram-negative infections had lower cytokine production than patients with gram-positive ones. This last group had IL- $1 \beta$ and IL-6 productions close to controls. In patients with a nonseptic shock only IL- $1 \alpha$ production was significantly lowered compared to controls.

A restoration of IL- $1 \alpha$ and IL- $1 \beta$ (Fig. 3), IL-6 and TNF $\alpha$ (Fig. 4) was found in septic patients who survived. After LPS stimulation, levels close to normal or even slightly higher for IL- 6 and TNF $\alpha$ were obtained. On the contrary, in septic patients who died, a lowered production of cytokines by monocytes upon LPS stimulation persisted until the last determination before death.

No correlation was found between the levels of cytokine produced by monocytes upon LPS stimulation and the severity score, the drugs which were used, or the nutritional status of the patients.



Figure 2. In vitro cytokine release upon $N$. meningitidis LPS activation of adherent monocytes from infected patients at admission in the ICU. Thick dashed lines represent the mean values of healthy controls and thin dashed lines represent \pm SEM. (Statistical analysis between controls and infected ICU patients: $P<0.01, P=0.09, P$ $<0.05$, and $P=0.06$ for IL- $1 \alpha$, IL-1 $\beta$, TNF $\alpha$, and IL-6, respectively). 
Table III. Levels of Cytokines Production by Monocytes Triggered by $1 \mu \mathrm{g}$ Neisseria meningitidis LPS, in Healthy Controls, Patients with Sepsis Syndrome and Nonseptic Shock (Minimal Levels during ICU Stay)

\begin{tabular}{|c|c|c|c|c|c|}
\hline & $\begin{array}{c}\text { Controls } \\
(n=11-19)\end{array}$ & $\begin{array}{l}\text { All infections } \\
\quad(n=23)^{*}\end{array}$ & $\begin{array}{c}\text { Gram }- \text { and }-/+ \\
(n=15)\end{array}$ & $\begin{array}{l}\text { Gram }+ \\
(n=7)\end{array}$ & $\begin{array}{c}\text { Nonseptic shock } \\
(n=6)\end{array}$ \\
\hline Released IL-1 $\alpha^{\ddagger}$ & $520 \pm 109^{8}$ & $149 \pm 38$ & $81 \pm 21$ & $316 \pm 93$ & $106 \pm 61$ \\
\hline$P^{\|}$ & & 0.001 & $<0.001$ & 0.24 & 0.03 \\
\hline Cell-associated IL-1 $\alpha$ & $6799 \pm 1119$ & $1823 \pm 401$ & $1114 \pm 380$ & $3548 \pm 702$ & $3023 \pm 576$ \\
\hline$P$ & & $<0.001$ & $<0.001$ & 0.07 & 0.05 \\
\hline Released IL-1 $\beta$ & $3375 \pm 528$ & $1523 \pm 348$ & $1023 \pm 251$ & $2795 \pm 857$ & $3153 \pm 1210$ \\
\hline$P$ & & 0.005 & $<0.001$ & 0.55 & 0.85 \\
\hline Cell associated IL-1 $\beta$ & $1921 \pm 354$ & $1102 \pm 185$ & $1012 \pm 255$ & $1428 \pm 209$ & $2016 \pm 380$ \\
\hline$P$ & & 0.03 & 0.04 & 0.42 & 0.75 \\
\hline IL-6 & $6245 \pm 1250$ & $2958 \pm 878$ & $2477 \pm 1127$ & $4380 \pm 1530$ & $4465 \pm 963$ \\
\hline$P$ & & 0.03 & 0.04 & 0.42 & 0.45 \\
\hline $\mathrm{TNF} \alpha$ & $4852 \pm 539$ & $1759 \pm 271$ & $1614 \pm 282$ & $2177 \pm 662$ & $4000 \pm 1257$ \\
\hline$P$ & & $<0.001$ & $<0.001$ & 0.008 & 0.47 \\
\hline
\end{tabular}

* Including one patient with tuberculosis; ${ }^{\ddagger} \mathrm{IL}-1 \alpha, \mathrm{IL}-1 \beta$, and TNF $\alpha$ measurements are expressed as pg/ml and IL-6 as U/ml;

' mean \pm SEM; " comparisons with values from healthy controls (Student $t$ test).

\section{Discussion}

Significant amounts of circulating cytokines in septic patients have been well documented since 1987 (10-18). In animal models half-life of i.v. injected TNF $\alpha$ is $\sim 6-7$ min (59). A biphasic plasma clearance has been described for IL-1 $\beta$ (60) and IL-6 (61) with an initial rapid disappearance of $3 \mathrm{~min}$ and a subsequent slower one (1-4 h). In this context, the fact that cytokines might be detectable in plasma over a long period of time as demonstrated in this study (61a) as well as in several other ones $(17,62)$ suggests an intensive and continuous production. The cellular origin of these circulating cytokines remains to be fully elucidated. In the literature, little information is available on cell-associated cytokines in freshly isolated monocytes. As it is well known that IL-1 can be accumulated within activated monocytes, investigations have been mainly concentrated on this cytokine $(46,47)$. IL- $1 \alpha$ is the main cell associated form of IL-1 in LPS-stimulated normal human monocytes $(63,64)$. Thus, it was surprising to find very rarely IL- $1 \alpha$ within the adherent cells isolated from septic patients. Cell-associated IL- $1 \beta$ was found in $56 \%$ of septic patients as well as in monocytes from patients with nonseptic shock. In our mind the discovery of frequent ( $90 \%$ patients) cell-associated TNF $\alpha$ in freshly isolated monocytes is interesting. Furthermore, cell-associated TNF $\alpha$ levels at admission $(267 \pm 55$ $\mathrm{pg} / \mathrm{ml})$ or maximum levels during ICU stay $(625 \pm 126 \mathrm{pg} / \mathrm{ml})$ were particularly high compared to those which could be detected in in vitro LPS-activated monocytes from healthy volunteers (i.e., $98 \pm 43 \mathrm{pg} / \mathrm{ml}$ ) (Munoz, C., unpublished results). It is noteworthy that TNF $\alpha$ appears as the most frequent cytokine in plasma and within monocytes. Although we found cell-associated TNF $\alpha$ and IL-1 $\beta$, their presence and amounts did not
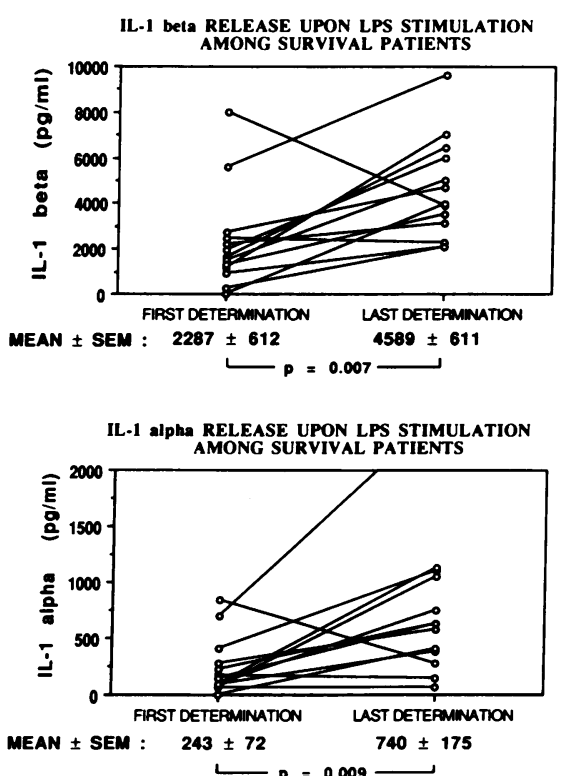
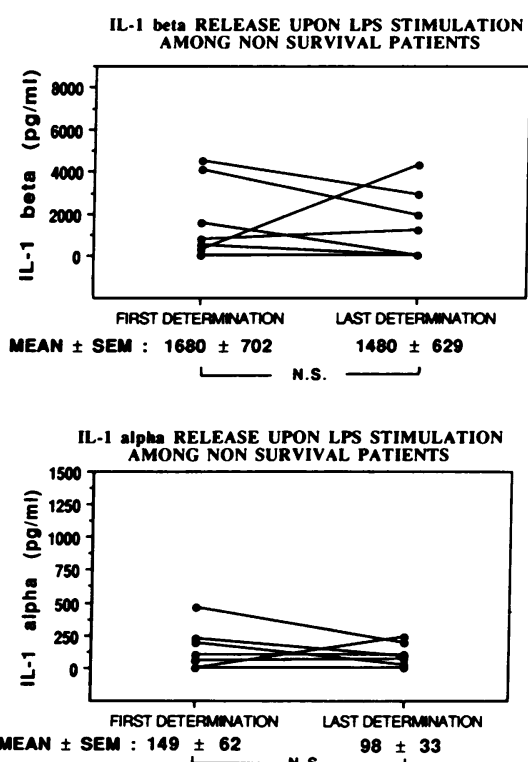

Figure 3. Comparison between first determinations (performed within $2 \mathrm{~d}$ after admission of the patients in the ICU) and last measurements (performed at the end of the followup of the patients) of LPS-induced IL- $1 \alpha$ and IL$1 \beta$ release by monocytes from survival $(n=13)$ and nonsurvival $(n=7)$ septic patients. The mean day of the last determination was $14 \pm 7$ and $10 \pm 5$ for the survival and the nonsurvival groups, respectively). 

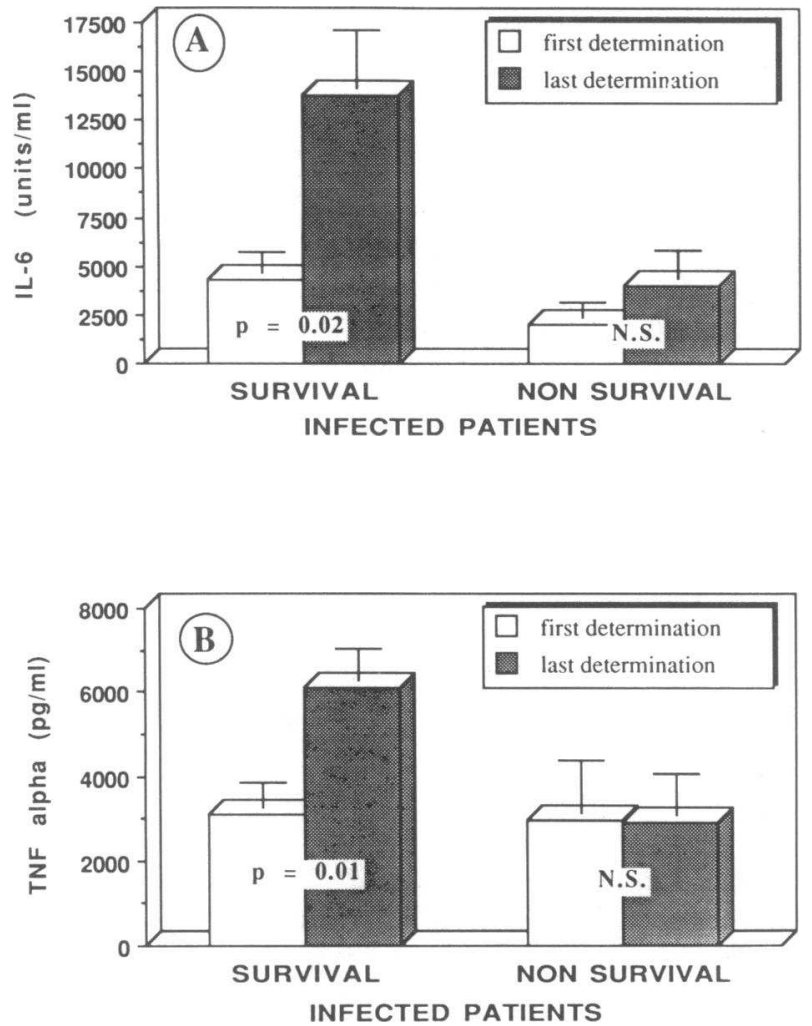

Figure 4. Comparison between first and last determinations of LPSinduced IL-6 $(A)$ and TNF $\alpha(B)$ in vitro production by monocytes from survival and nonsurvival septic patients.

correlate with the levels of the corresponding circulating cytokines. However, it is likely that measurable circulating cytokines represent the excess of produced cytokines. One could assume that in vivo "reasonable" production would not be detected in plasma because all cytokines would be trapped by their specific high-affinity receptors on host cells. Indeed in the last determinations performed in survival patients, TNF $\alpha$ was often detected within freshly isolated monocytes, whereas plasma TNF $\alpha$ levels were back under detection limit values. Furthermore, the absence of correlation between plasma and cell-associated levels might also suggest that circulating monocytes are not the only sources of circulating cytokines and that other cells, like Kupffer cells or alveolar macrophages, could also participate to this production.

When monocytes were cultured in the absence of any stimuli, spontaneous release of TNF $\alpha$ and IL-1 $\beta$ were not significantly higher than in controls (data not shown). In this study we have investigated the behavior of isolated monocytes to respond in vitro to an LPS-induced activation. In septic patients, we found a profound impairment of LPS-induced IL$1 \alpha$, IL-1 $\beta$, TNF $\alpha$, and IL-6 productions which were dramatically decreased. We have chosen optimal culture conditions (i.e., in the presence of indomethacin and $0.2 \%$ normal human serum) for which we established the levels of IL-1 $\alpha$, IL-1 $\beta$, TNF $\alpha$, and IL- 6 produced by monocytes from normal healthy donors. Among peripheral blood mononuclear cells, a rather higher number of nonspecific esterase positive (NSE+) cells was obtained in the beginning of the follow up of the septic patients. As a constant number of input NSE+ cells were cultured, a comparison between different cultures was possible. We did not observe any differences in adherence properties of monocytes from normal donors or septic patients. In the group of patients with noninfectious shock, a reduced production of IL-1 $\alpha$ was also noticed, whereas this was not the case for IL-1 $\beta$, IL-6, and TNF $\alpha$. This observation confirms the fact that the regulation of IL- $1 \alpha$ and IL- $1 \beta$ productions are under distinct pathways (65). This downregulation of cytokine production was especially significant for patients with gram-negative infections. In agreement with our findings, a recent case report indicates that IL-1 activity produced by monocytes from two children with Haemophilus influenza meningitis upon LPS stimulation was significantly reduced (66). On the contrary Fieren et al. (67) reported that peritoneal macrophages from patients on continuous ambulatory peritoneal dialysis with infectious peritonitis, had an increased IL- $1 \beta$ release upon in vitro challenge with LPS. In this study, only one of eight patients had a gramnegative infection.

Interestingly, the observed down production of cytokine production upon LPS stimulation was a transient event in survival patients. At the end of the survey, they recovered levels of in vitro cytokine productions close to those of healthy controls. Although this finding was expected, it ensured that despite a well-known interindividual heterogeneity in cytokine production, comparison could be made between groups.

The mechanisms underlying these phenomena remain to be fully elucidated and further experiments should address the question whether this dysregulation is a transcriptional or a posttranscriptional event, as shown in the rabbit model (68). Different parameters can be suggested to explain this dysregulation. Stress is known to generate a decrease immune responsiveness. However, we did not find any correlation between the severity scores and the levels of in vitro cytokine productions. Differences were found in IL-1 $\beta$, IL-6, and TNF $\alpha$ production between patients with sepsis syndrome and patients with noninfectious shock although they had rather similar severity scores. Furthermore, the reduced production was not predictive for the outcome (recovery or death). All patients received different drugs; although none was directly associated with the observed phenomenom, one cannot exclude that an association between some of them may modify the in vitro cytokine production. However, the recovery of normal levels of cytokine productions among survival patients was observed while patients were still receiving most of these drugs. The nutritional status is also a factor which could influence the in vitro cytokine production. However, infected and noninfected groups had rather similar nutritional status. Because the phenomenon was mainly associated with gram-negative infection, we can hypothesize that our observation might account for the welldescribed endotoxin tolerance (69) which is accompanied by a decreased LPS-induced TNF $\alpha$ production $(68,70,71)$. This is currently investigated using other stimuli than LPS to know whether this downregulation is specific for this activator. Indeed, Takayama et al. (72), using gamma interferon and muramyl dipeptide as inducers, showed that patients with sepsis had a greater TNF $\alpha$ production, as compared to normal controls.

The presence of cell-associated cytokine in circulating monocytes and the down regulation observed upon a further in vitro activation suggest the existence of complex regulatory mechanisms, and further experiments are required to under- 
stand the relative roles of the different populations of mononuclear phagocytes.

\section{Acknowledgments}

We are very grateful to Dr. Jean-Claude Mazié (Hybridolab, Institut Pasteur) for his fruitful collaboration in the preparation of anti-human IL- $\alpha$ monoclonal antibodies. We thank Françoise Fouque (Department des Enseignements, Institut Pasteur) for her contribution in the set up of the ELISA for IL- $1 \alpha$, Catherine Rougeot (Unité de RIA, Institut Pasteur) for her gift of rabbit anti-human TNF $\alpha$ and her valuable discussion in the set up of the RIA for TNF $\alpha$, and Dr. Jacques Van Snick (Ludwig Institut for Cancer Research, Brussels) for his gift of the 7TD1 cell line. We thank Marie-Francoise Dumay (Intensive Care Unit, Hôpital St. Joseph) for her efficient collaboration.

Carlos Munoz was supported by the Fondation pour la Recherche Médicale.

\section{References}

1. Shalaby, M. R., A. Waage, L. Aarden, and T. Espevik. 1989. Endotoxin, tumor necrosis factor- $\alpha$ and interleukin-1 induce interleukin 6 production in vivo. Clin. Immunol. Immunopathol. 53:488-498.

2. Evans, G. F., Y. M. Snyder, L. D. Butler, and S. H. Zuckerman. 1989. Differential expression of interleukin-1 and tumor necrosis factor in murine septic shock models. Circ. Shock. 29:279-290.

3. Ikejima, T., S. Okusawa, J. W. M. Van Der Meer, and C. A. Dinarello. 1989. Toxic shock syndrome is mediated by interleukin 1 and tumor necrosis factor. Rev. Infect. Dis. 11(Suppl. 1):S316-S317.

4. Adams, J. L., S. R. Semrad, and C. J. Czuprynski. 1990. Administration of bacterial lipopolysaccharide elicits circulating tumor necrosis factor-alpha in neonatal calves. J. Clin. Microbiol. 28:998-1001.

5. Fong, Y., and S. F. Lowry. 1990. Tumor necrosis factor in the pathophysiology of infection and sepsis. Clin. Immunol. Immunopathol. 55:157-170.

6. LeMay, D. R., L. G. LeMay, M. J. Kluger, and L. G. D'Alecy. 1990. Plasma profiles of IL-6 and TNF with fever-inducing doses of lipopolysaccharide in dogs. Am. J. Physiol. 259:R126-R132.

7. Waage, A., A. Halstensen, R. Shalaby, P. Brandtzag, P. Kierulf, and T. Espevik. 1989. Local production of tumor necrosis factor $\alpha$, interleukin 1, and interleukin 6 in meningococcal meningitis. Relation of the inflammatory response. J. Exp. Med. 170:1859-1867.

8. Michie, H. R., K. R. Manogue, D. R. Spriggs, A. Revhaug, S. O'Dwyer, C. A. Dinarello, A. Cerami, S. M. Wolff, and D. W. Wilmore. 1988. Detection of circulating tumor necrosis factor after endotoxin administration. N. Engl. J. Med. 318:1481-1486.

9. Fong, Y., L. L. Moldawer, M. Marano, H. Wei, S. B. Tatter, R. H. Clarick, U. Santhanam, D. Sherris, L. T. May, P. B. Sehgal, and S. F. Lowry. 1989. Endotoxemia elicits increased circulating $\beta_{2}$-INF/IL-6 in man. J. Immunol. 142:2321-2324.

10. Cannon, J. G., R. G. Tompkins, J. A. Gelfand, H. R. Michie, G. G. Stanford, J. W. M. Van Der Meer, S. Endres, G. Lonnemann, J. Corsetti, B. Chernow, D. W. Wilmore, S. M. Wolff, J. F. Burke, and C. A. Dinarello. 1990 Circulating interleukin-1 and tumor necrosis factor in septic shock and experimental endotoxin fever. J. Infect. Dis. 161:79-84.

11. Waage, A., A. Halstensen, and T. Espevik. 1987. Association between tumour necrosis factor in serum and fatal outcome in patients with meningococcal disease. Lancet. 14:355-357.

12. Girardin, E., G. E. Grau, J. M. Dayer, P. Roux-Lombard, The J5 Study Group, and P. H. Lambert. 1988. Tumor necrosis factor and interleukin-1 in the serum of children with severe infectious purpura. N. Engl. J. Med. 319:397-400.

13. Waage, A., P. Brandtzæg, A. Halstensen, P. Kierulf, and T. Espevik. 1989 The complex pattern of cytokines in serum from patients with meningococcal septic shock. Association between interleukin 6, interleukin-1, and fatal outcome. J. Exp. Med. 169:333-338.

14. Helfgott, D. C., S. B. Tatter, U. Santhanam, R. H. Clarick, N. Bhardwaj, L. T. May, and P. B. Sehgal. 1989. Multiple forms of INF- $\beta_{2} / \mathrm{IL}-6$ in serum and body fluids during acute bacterial infection. J. Immunol. 142:948-953.

15. Hack, C. E., E. R. De Groot, R. J. F. Felt-Bersma, J. H. Nuijens, R. J. M. Strack Van Schijndel, A. J. M. Eerenberg-Belmer, L. G. Thijs, and L. A. Aarden. 1989. Increased plasma levels of interleukin-6 in sepsis. Blood. 74:1704-1710.

16. De Groot, M. A., M. A. Martin, P. Densen, M. A. Pfalle, and R. P. Wenzel. 1989. Plasma tumor necrosis factor levels in patients with presumed sepsis. J. Am. Med. Assoc. 262:249-251.
17. Calandra, T., J. D. Baumgartner, G. E. Grau, M. M. Wu, P. H. Lambert, J. Schellekens, J. Verhoef, M. P. Glauser, and the Swiss-Dutch J5 Immunoglobulin Study Group. 1990. Prognostic values of tumor necrosis factor/cachectin, interleukin-1, interferon- $\alpha$, and interferon- $\gamma$ in the serum of patients with septic shock. J. Infect. Dis. 161:982-987.

18. Marks, J. D., C. Berman-Marks, J. M. Luce, A. B. Montgomery, J. Turner, C. A. Metz, and J. F. Murray. 1990. Plasma tumor necrosis factor in patients with septic shock. Mortality rate, incidence of adult respiratory distress syndrome, and effects of methylprednisolone administration. Am. Rev. Respir. Dis. 141:94-97.

19. Marano, M. A., Y. Fong, L. L. Moldawer, H. Wei, S. E. Calvano, K. J. Tracey, P. S. Barie, K. Manogue, A. Cerami, G. T. Shires, and S. F. Lowry. 1990. Serum cachectin/tumor necrosis factor in critically ill patients with burns correlates with infection and mortality. Surg. Gynecol. \& Obstet. 170:32-38.

20. Goldblum, S. E., K. Yoneda, D. A. Cohen, and C. J. McClain. 1988 Provocation of pulmonary vascular endothelial injury in rabbits by human recombinant interleukin-1 $\beta$. Infect. Immun. 56:2255-2263.

21. Stephens, K. E., A. Ishizaka, Z. Wu, J. W. Larrick, and T. A. Raffin. 1988. Granulocyte depletion prevents tumor necrosis factor-mediated acute lung injury in guinea pigs. Am. Rev. Respir. Dis. 138:1300-1307.

22. Jacobs, R. F., D. R. Tabor, A. W. Burks, and G. D. Campbell. 1989 Elevated interleukin-1 release by human alveolar macrophages during the adult respiratory distress syndrome. Am. Rev. Respir. Dis. 140:1686-1692.

23. Ferrari-Baliviera, E., K. Mealy, R. J. Smith, and D. W. Wilmore. 1989. Tumor necrosis factor induces adult respiratory distress syndrome in rats. Arch. Surg. 124:1400-1405.

24. Okusawa, S., J. A. Gelfand, T. Ikejima, R. J. Connolly, and C. A. Dinarello. 1988. Interleukin 1 induces a shock-like state in rabbits. Synergism with tumor necrosis factor and the effect of cyclooxygenase inhibition. J. Clin. Invest. 81:1162-1172.

25. Dunn, C. J., R. G. Schaub, W. E. Fleming, and A. J. Gibbons. 1989 Interleukin-1 induced vascular pathology in vivo: a scanning electron-microscopy study. Agents Actions. 27:287-289.

26. Natanson, C., P. W. Eichenholz, R. L. Danner, P. Q. Eichacker, W. D. Hoffman, G. C. Kuo, S. M. Banks, T. J. MacVittie, and J. E. Parrillo. 1989. Endotoxin and tumor necrosis factor challenges in dogs simulate the cardiovascular profile of human septic shock. J. Exp. Med. 169:823-832.

27. Bevilacqua, M. P., J. S. Pober, G. R. Majeau, W. Fiers, R. S. Cotran, and M. A. Gimbrone. 1986. Recombinant tumor necrosis factor induces procoagulant activity in cultured human vascular endothelium: characterization and comparison with the actions of interleukin 1. Proc. Natl. Acad. Sci. USA. 83:45334557.

28. Van Der Poll, T., H. R. Büller, H. Ten Cate, C. H. Wortel, K. A. Bauer, S. J. H. Van Deventer, C. E. Hack, H. P. Sauerwein, R. D. Rosenberg, and J. W. Ten Cate. 1990. Activation of coagulation after administration of tumor necrosis factor to normal subjects. $N$. Engl. J. Med. 322:1622-1625.

29. Cybulsky, M. I., H. Z. Movat, and C. A. Dinarello. 1987. Role of interleukin-1 and tumor necrosis factor- $\alpha$ in acute inflammation. Ann. Inst. Pasteur/Immunol. 138:505-512.

30. Saukkonen, K., S. Sande, C. Cioffe, S. Wolpe, B. Sherry, A. Cerami, and E. Tuomanen. 1990. The role of cytokines in the generation of inflammation and tissue damage in experimental gram-positive meningitis. J. Exp. Med. 171:439448 .

31. Gauldie, J., C. Richards, D. Harnish, P. Lansdorp, and H. Baumann. 1987. Interferon $\beta_{2}$ /B-cell stimulatory factor type 2 shares identity with monocyte-derived hepatocyte-stimulating factor and regulates the major acute phase protein response in liver cells. Proc. Natl. Acad. Sci. USA. 84:7251-7255.

32. Ramadori, G., J. Van Damme, H. Rieder, and K. H. Meyer zum Büschenfelde. 1988. Interleukin 6, the third mediator of acute-phase reaction, modulates hepatic protein synthesis in human and mouse. Comparison with interleukin $1 \beta$ and tumor necrosis factor- $\alpha$. Eur. $J$. Immunol. 18:1259-1264.

33. Gauldie, J., W. Northemann, and G. H. Fey. 1990. IL-6 functions as an exocrine hormone in inflammation. Hepatocytes undergoing acute phase responses require exogenous IL-6. J. Immunol. 144:3804-3808.

34. Opp, M., F. Obal, A. B. Cady, L. Johannsen, and J.-M. Krueger. 1989. Interleukin-6 is pyrogenic but not somnogenic. Physiol. \& Behav. 45:1069-1072.

35. LeMay, L. G., I. G. Otterness, A. J. Vander, and M. J. Kluger. 1990. In vivo evidence that the rise in plasma IL 6 following injection of a fever-inducing dose of LPS is mediated by IL 1 1 . Cytokines. 2:199-204.

36. Jablons, D. M., J. J. Mulé, J. K. McIntosh, P. B. Sehgal, L. T. May, C. M Huang, S. A. Rosenberg, and M. T. Lotze. 1989. IL-6/INF- $\beta-2$ as a circulating hormone. Induction by cytokine administration in humans. J. Immunol. 142:1542-1547.

37. Brouckaert, P., D. R. Spriggs, G. Demetri, D. W. Kufe, and W. Fiers. 1989. Circulating interleukin-6 during a continuous infusion of tumor necrosis factor and interferon $\gamma . J$. Exp. Med. 169:2257-2262.

38. De Simoni, M. G., M. Sironi, A. De Luigi, A. Manfridi, A. Mantovani, and P. Ghezzi. 1990. Intracerebroventricular injection of interleukin-1 induces high circulating levels of interleukin-6. J. Exp. Med. 171:1773-1778. 
39. Smith, D. M., G. A. Lackides, and L. B. Epstein. 1990. Coordinated induction of autocrine tumor necrosis factor and interleukin-1 in normal human monocytes and the implications for monocyte-mediated cytotoxicity. Cancer Res. 50:3146-3153.

40. Ikejima, T., S. Okusawa, P. Ghezzi, J. W. M. Van Der Meer, and C. A Dinarello. 1990. Interleukin-1 induces tumor necrosis factor (TNF) in human peripheral blood mononuclear cells in vitro and a circulating TNF-like activity in rabbits. J. Infect. Dis. 162:215-223.

41. Movat, H. Z., C. E. Burrowes, M. I. Cybulsky, and C. A. Dinarello. 1987. Acute inflammation and a Shwartzman-like reaction induced by interleukin-1 and tumor necrosis factor. Synergistic action of the cytokines in the induction of inflammation and microvascular injury. Am. J. Pathol. 129:463-476.

42. Baumann, H., C. Richards, and J. Gauldie. 1987. Interaction among hepatocyte-stimulating factors, interleukin 1 , glucocorticoids for regulation of acute phase plasma proteins in human hepatoma (HepG2) cells. J. Immunol. 139:4122-4128.

43. Last-Barney, K., C. A. Homon, R. B. Faanes, and V. J. Merluzzi. 1988. Synergistic and overlapping activities of tumor necrosis factor- $\alpha$ and IL-1. $J$. Immunol. 141:527-530.

44. Andus, T., T. Geiger, T. Hirano, T. Kishimoto, and P. C. Heinrich. 1988 Action of recombinant human interleukin 6 , interleukin $1 \beta$ and tumor necrosis factor $\alpha$ on the mRNA induction of acute-phase proteins. Eur. J. Immunol. 18:739-746.

45. Rothstein, J. L., and H. Schreiber. 1988. Synergy between tumor necrosis factor and bacterial products causes hemorrhagic necrosis and lethal shock in normal mice. Proc. Natl. Acad. Sci. USA. 85:607-611.

46. Haeffner-Cavaillon, N., J.-M. Cavaillon, C. Ciancioni, F. Bacle, S. Delons, and M. D. Kazatchkine. 1989. In vivo induction of interleukin-1 during hemodialysis. Kidney Int. 35:1212-1218.

47. Haeffner-Cavaillon, N., N. Roussellier, O. Ponzio, M. P. Carreno, M Laude, A. Carpentier, and M. D. Kazatchkine. 1989. Induction of interleukin-1 production in patients undergoing cardiopulmonary bypass. J. Thorac. Cardio vasc. Surg. 98:1100-1106.

48. Bone, R. C., C. J. Fisher, T. P. Clemmer, G. J. Slotman, G. A. Metz, R. A Balk, and the Methylprednisolone Severe Sepsis Study Group. 1989. Sepsis syndrome: a valid clinical entity. Crit. Care Med. 17:389-397.

49. Le Gall, J. R., P. Loirat, A. Alperovitch, P. Glaser, C. Granthil, D. Mathieu, P. Mercier, R. Thomas, and D. Villers. 1984. A simplified acute physiology score for ICU patients. Crit. Care Med. 12:975-982.

50. Tucker, S. B., R. V. Pierre, and R. E. Jordon. 1977. Rapid identification of monocytes in a mixed mononuclear cell preparation. J. Immunol. Methods. 14:267-269.

51. Cavaillon, J.-M., C. Fitting, and N. Haeffner-Cavaillon. 1990. Recombinant C5a enhances interleukin 1 and tumor necrosis factor release by lipopolysaccharide-stimulated monocytes and macrophages. Eur. J. Immunol. 20:253-257.

52. Cavaillon, J.-M., C. Fitting N. Haeffner-Cavaillon, S. J. Kirsch, and H. S. Warren. 1990. Cytokine response by monocytes and macrophages to free and lipoprotein-bound lipopolysaccharide. Infect. Immun. 58:2375-2382.

53. Cavaillon, J.-M., and N. Haeffner-Cavaillon. 1987. Characterization of the induction of human interleukin 1 by endotoxins. NATO ASI (Adv. Sci. Inst.) Ser. A. 139:395-408.

54. Van Snick, J., S. Cayphas, A. Vink, C. Uyttenhove, P. G. Coulie, M. R. Rubira, and R. J. Simpson. 1986. Purification and $\mathrm{NH}_{2}$-terminal amino acid sequence of a T-cell-derived lymphokine with growth factor activity for B-cell hybridomas. Proc. Natl. Acad. Sci. USA. 83:9679-9683.

55. Hansen, M. B., S. E. Nielsen, and K. Berg. 1989. Re-examination and further development of a precise and rapid dye method for measuring cell growth/cell kill. J. Immunol. Methods. 119:203-210.

56. Van Der Meer, J. W. M., S. Endres, G. Lonnemann, J. G. Cannon, T. Ikejima, S. Okusawa, J. A. Gelfand, and C. A. Dinarello. 1988. Concentrations of immunoreactive human tumor necrosis factor alpha produced by human mononuclear cells in vitro. J. Leukocyte Biol. 43:216-223.

57. Cannon, J. G., J. W. M. Van Der Meer, D. Kwiatkowski, S. Endres, G. Lonnemann, J.-F. Burke, and C. A. Dinarello. 1988. Interleukin-1 $\beta$ in human plasma: optimization of blood collection, plasma extraction and radioimmunoassay methods. Lymphokine Res. 7:457-467.

58. Kearney, J. F., A. Radbruch, B. Niesegang, and K. Rajewsky. 1979. A new mouse myeloma line that has lost immunoglobulin expression but permits the construction of antibody-secreting hybrid cell lines. J. Immunol. 123:1548-1550.

59. Beutler, B. A., I. W. Milsark, and A. Cerami. 1985. Cachectin/tumor necrosis factor: production, distribution, and metabolic fate in vivo. J. Immunol. 135:3972-3977.

60. Klapproth, J., J. Castell, T. Yeiger, T. Andus, and P. C. Heinrich. 1989 Fate and biological action of human recombinant interleukin $1 \beta$ in the rat in vivo. Eur. J. Immunol. 19:1485-1490.

61. Castell, J. V., T. Geiger, V. Gross, T. Andus, E. Walter, T. Hirano, T. Kishimoto, and P. C. Heinrich. 1988. Plasma clearance, organ distribution and target cells of interleukin-6/hepatocyte-stimulating factor in the rat. Eur. J. Biochem. 177:357-361.

61a. Munoz, C., B. Misset, C. Fitting, J. P. Blériot, J. Carlet, and J.-M. Cavaillon. 1991. Dissociation between plasma and monocyte-associated cytokines during sepsis. Eur. J. Immunol. 21:2177-2184.

62. Offner, F., J. Philippé, D. Vogelaers, F. Colardyn, T. Baele, M. Baudrihaye, A. Vermeulen, and G. Leroux-Roels. 1990. Serum tumor necrosis factor levels in patients with infectious disease and septic shock. J. Lab. Clin. Med. 116:100-105.

63. Endres, S., J. G. Cannon, R. Ghorbani, R. A. Dempsey, S. D. Sisson, G. Lonnemann, J. W. M. Van Der Meer, S. M. Wolff, and C. A. Dinarello. 1989. In vitro production of IL $1 \beta$, IL $1 \alpha$, TNF and IL 2 in healthy subjects: distribution, effect of cyclooxygenase inhibition and evidence of independent gene regulation. Eur. J. Immunol. 19:2327-2327.

64. Cavaillon, J.-M., and N. Haeffner-Cavaillon. 1990. Signals involved in interleukin 1 synthesis and release by lipopolysaccharide-stimulated monocytes/ macrophages. Cytokines. 2:313-329.

65. Bailly, S., Y. Mahe, B. Ferrua, M. Fay, T. Tursz, H. Wakasugi, and M.-A. Gougerot-Pocidalo. 1990. Quinolone-induced differential modification of IL-1 $\alpha$ and IL-1 $\beta$ production by LPS-stimulated human monocytes. Cell. Immunol. 128:277-288.

66. Helminen, M., and T. Vesikari. 1990. Interleukin-1 production in bacterial meningitis. Scand. J. Infect. 22:105-108.

67. Fieren, M. W. J. A., G. J. C. M. Van den Bemd, and I. L. Bonta. 1990. Endotoxin-stimulated peritoneal macrophages obtained from continuous ambuloatory peritoneal dialysis patients show an increased capacity to release interleukin- $1 \beta$ in vitro during infectious peritonitis. Eur. J. Clin. Invest. 20:453-457.

68. Mathison, J. C., G. D. Virca, E. Wolfson, P. S. Tobias, K. Glaser, and R. J. Ulevitch. 1990. Adaptation to bacterial lipopolysaccharide controls lipopolysaccharide-induced tumor necrosis factor production in rabbit macrophages. J. Clin. Invest. 85:1108-1118.

69. Johnston, C. A., and S. E. Greisman. 1985. Mechanisms of endotoxin tolerance. In Pathophysiology of Endotoxin. Vol. 2. R. A. Proctor and L. B. Hinshaw, editors. Elsevier Science Publishers, Amsterdam. 359-401.

70. Sanchez-Cantu, L., H. N. Rode, and N. V. Christou. 1989. Endotoxin tolerance is associated with reduced secretion of tumor necrosis factor. Arch. Surg. 124:1432-1435.

71. Haas, J. G., C. Thiel, K. Blömer, E. H. Weiss, G. Riethmüller, and H. W. Ziegler-Heitbrock. 1989. Downregulation of tumor necrosis factor expression in the human mono-Mac-6 cell line by lipopolysaccharide. J. Leukocyte Biol. 46:11-14.

72. Takayama, T. K., C. Miller, and G. Szabo. 1990. Elevated tumor necrosis factor $\alpha$ production concomitant to elevated prostaglandin $\mathrm{E}_{2}$ production by trauma patients' monocytes. Arch. Surg. 125:29-35. 